\title{
MAMMALS AROUND THE NORTH END OF LAST MOUNTAIN LAKE
}

CLINT JORGENSON, Canadian Wildlife Service, Box 280, Simpson, Saskatchewan. SOG $4 \mathrm{MO}$

The following list of 32 mammals is compiled from records of field work by Gary Anweiler in 1969, from the small mammal live trapping records of E.A. Driver, 1983-1986, and from personal observations made from 1973 to date. ${ }^{14}$ The small mammal trapping by Driver confirmed the presence of several species. Records for 13 Christmas Mammal Counts (CMC) for the Last Mountain Lake area, compiled by W.C. Harris, are included (Table 1). The author's interpretation of the chances of sighting an individual species is given, however, this is very subjective and varies from year to year. Common names are taken from The mammals of Canada by A.W.F. Banfield. ${ }^{2}$

\section{Masked Shrew}

Anweiler listed this species as hypothetical with two summer sightings. Driver confirmed its occurrence by live trapping a specimen. This species is rarely seen.

\section{Silver-haired Bat}

Anweiler captured a single specimen on 9 May 1969. Bats are rarely seen.

\section{Snowshoe Hare}

Anweiler recorded a small colony in a farmstead shelterbelt and in June of 1969 found a nest with six young. Hare tracks were seen on 7 of the last 13 CMCs. One was recorded in an old area farmstead 17 March 1985. Hares are rarely seen in this area.

\section{White-tailed Jack Rabbit}

Jack rabbits were recorded on all 13 CMCs with numbers varying considerably. They are very commonly seen in all types of upland habitats.

\section{Richardson's Ground Squirrel}

During 1969 Anweiler found two small colonies of two or three pairs of Richardson's Ground Squirrel. Driver saw but did not trap the species. It is very common, especially in grazed pasture areas.

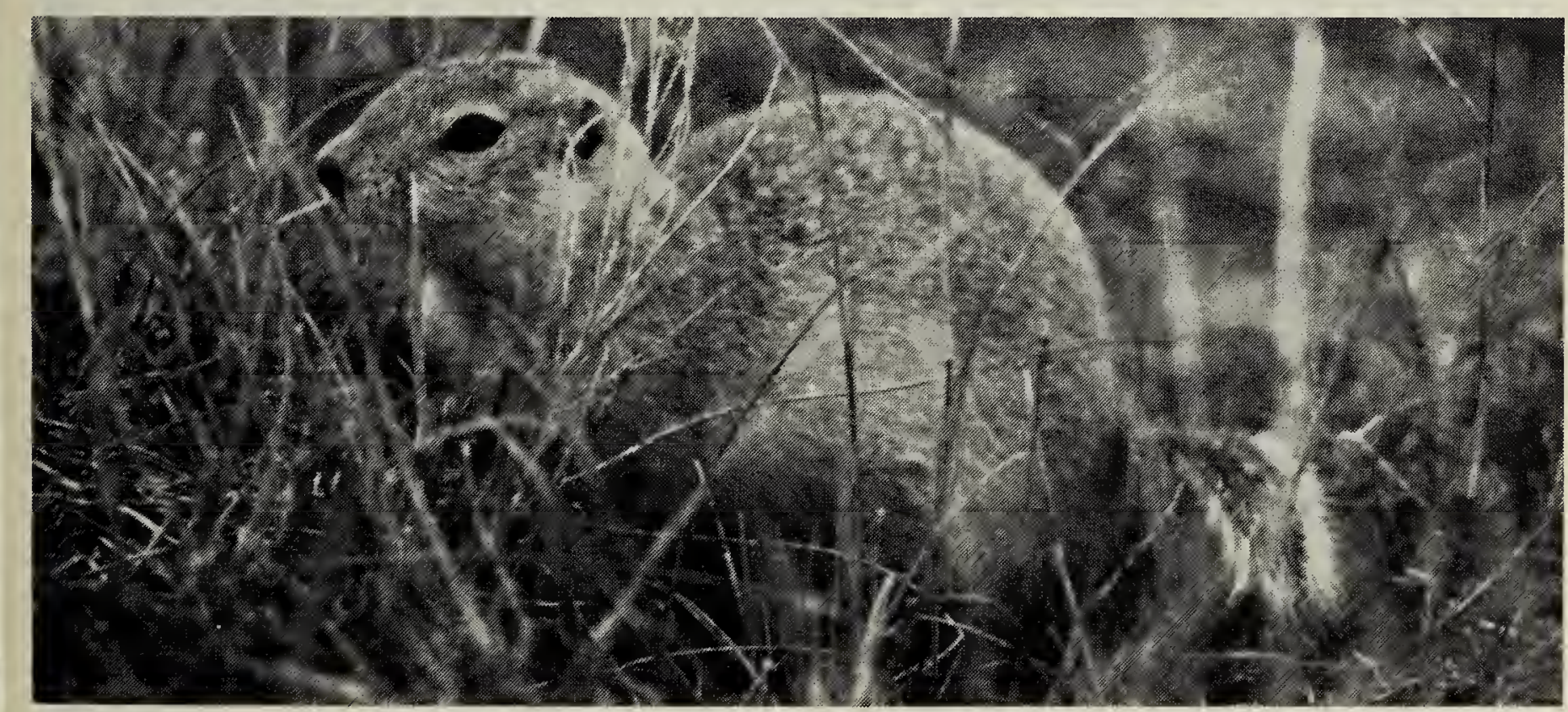

Richardson's Ground Squirrel

G.W. Beyersbergen 


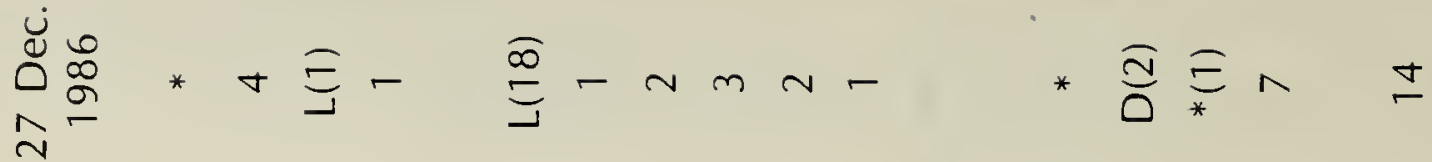

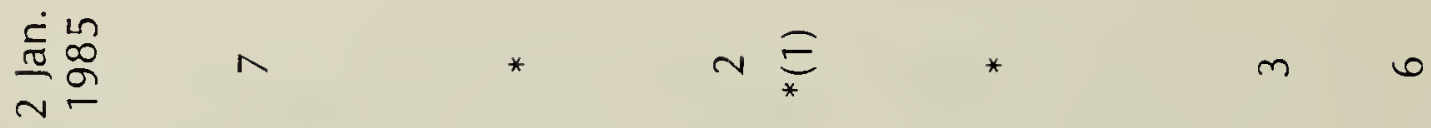

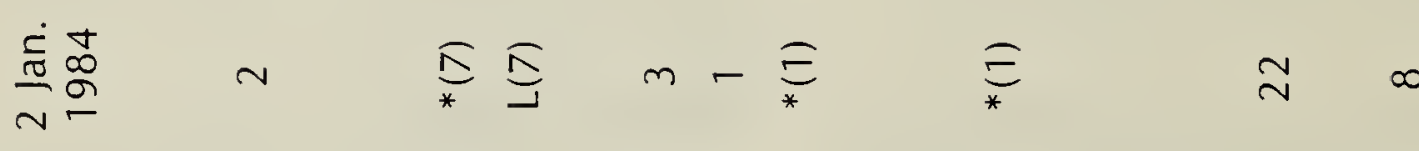

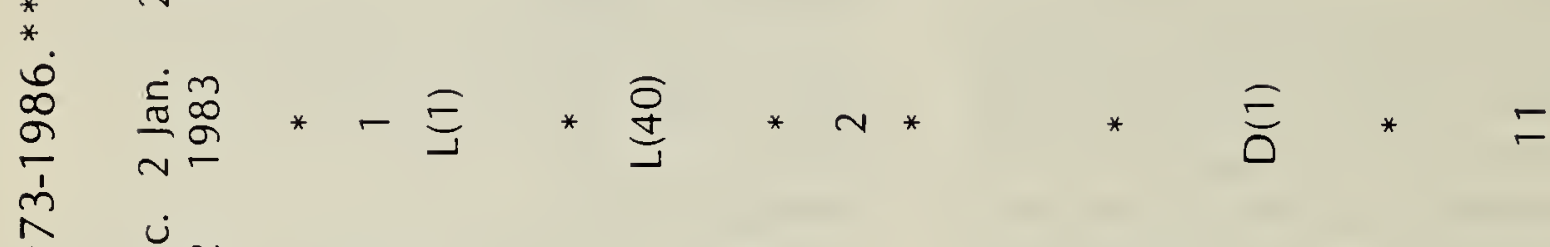

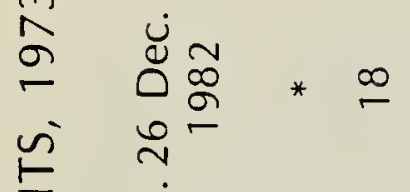

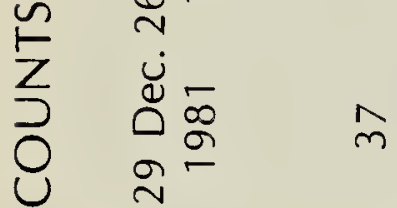

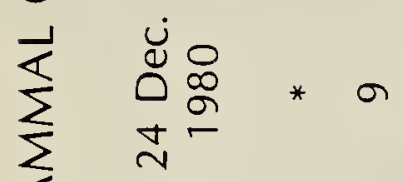

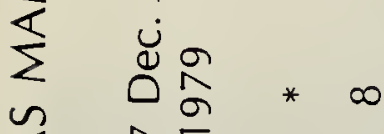

$\sum_{i}^{\infty} i^{n}$

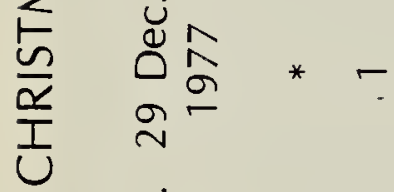

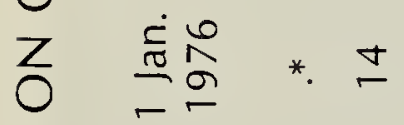

岸造朵

z $\stackrel{\infty}{\sim} \stackrel{\circ}{-}$

艺这志

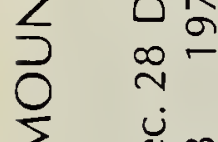

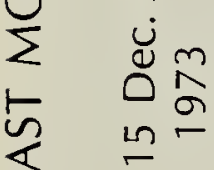

s in

飞

岀

$\sum_{1}^{\infty} \quad \frac{\pi}{\frac{\pi}{0}}$

$\sum_{i}^{\infty} \quad \frac{0}{\frac{0}{\pi}} \frac{i}{0}$

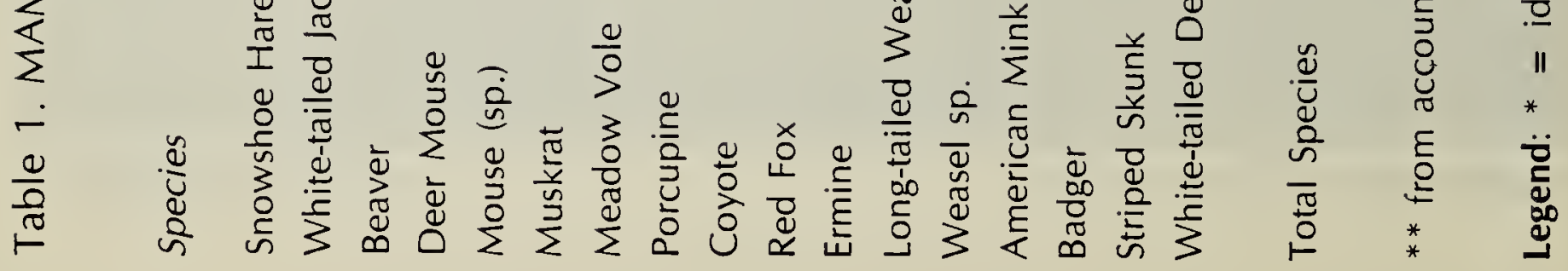


Thirteen-lined Ground Squirrel

Anweiler did not see this species until late summer and early fall of 1969. Driver classed it as common to rare from 1983 to 1986 . The author has seen this species on an annual basis since 1973 but the population has varied considerably. It is commonly sighted.

\section{Franklin's Ground Squirrel}

Anweiler had three sightings during 1969 and the author has had the occasional sighting since 1973, but the Franklin's Ground Squirrel is uncommonly seen.

\section{Northern Pocket Gopher}

Driver found fresh diggings in native prairie. The status of this species is uncertain but it is expected in moist, deep soils.

\section{Olive-backed Pocket Mouse}

Anweiler found a single pocket mouse dead on a cattle trail in May 1969. Nero gives the following records for this area: Hatfield, 7 mi. west, 17 September 1959 - 14 collected. ${ }^{6}$ Last Mountain Lake, west of Govan, 26 September 1961 - one collected. ${ }^{7}$ This mouse is rarely seen.

\section{Beaver}

Beaver were not mentioned by Anweiler but sightings occur most years and beaver lodges are not uncommon in deeper wetlands. One lodge was recorded on the 1983 and 1986 CMC.

\section{Deer Mouse}

The Deer Mouse is classed as a very common species by both Anweiler and Driver. It was recorded on one CMC.

\section{Gapper's Red-backed Vole}

This species was live trapped by Driver and listed as rare.

\section{Muskrat}

The Muskrat is very common in all marsh areas.

\section{Meadow Vole}

The Meadow Vole was listed as abundant by Anweiler in 1969 and Driver classed it as common to rare from his trapping records. It has been recorded on two CMCs and is a commonly seen mammal.

\section{Norway Rat}

Norway Rats are fairly common around

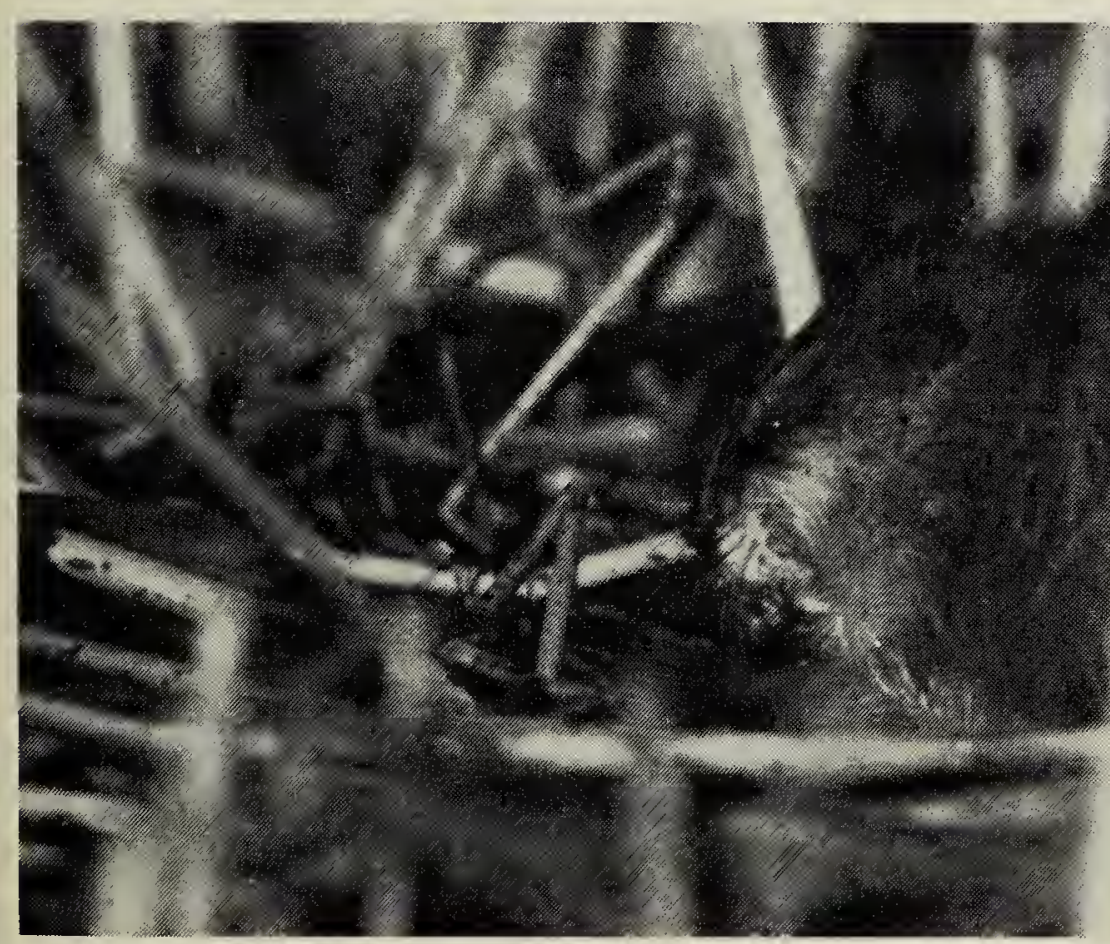

Muskrat

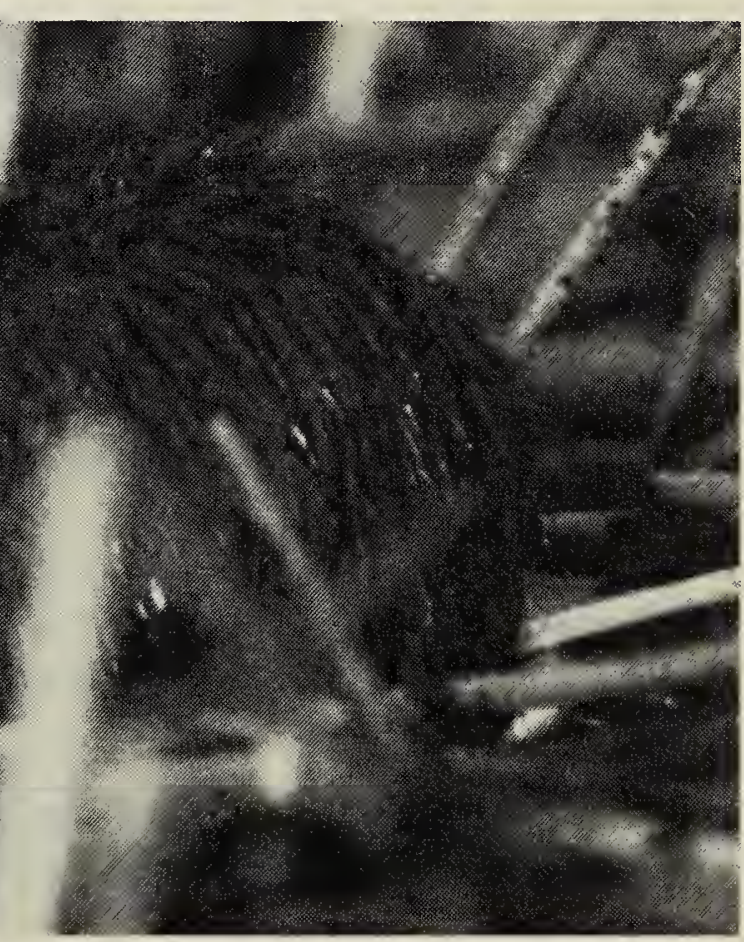

G.W. Beyersbergen 
many old, unkept buildings in the district.

\section{House Mouse}

A few House Mice were noted by Anweiler. They are occasionally seen in and around buildings.

\section{Western Jumping Mouse}

The Western Jumping Mouse was live trapped by Driver and listed as common to rare during his research 1983-1986.

\section{Meadow Jumping Mouse}

A jumping mouse seen by Anweiler in the garden at Canadian Wildlife Service Headquarters at the north end of Last Mountain Lake was possibly this species. It was classed by Anweiler as hypothetical and since there are no new records to add it remains hypothetical.

\section{Porcupine}

Anweiler saw Porcupine on at least six occasions, often in snowberry far out on the prairie. They were recorded on 9 of the $13 \mathrm{CMCs}$. The Porcupine is common and seen in all types of upland habitats.

\section{Coyote}

Anweiler recorded Coyotes on only two occasions in 1969 but it has been commonly seen and heard for the last few years. It was recorded on 11 of the 13 CMCs.

\section{Red Fox}

Anweiler listed the Red Fox as rarely seen but probably not uncommon. Foxes were recorded on 9 of the $13 \mathrm{CMCs}$ with no observations for the years 1977 to 1980 inclusive. In recent years it has been a very common species for the area and often seen.

\section{Raccoon}

Raccoons were not seen or mentioned by Anweiler in 1969, but are now fairly common in this area although seldom seen. Tracks can be found around most wetlands.

\section{Ermine}

Anweiler saw this species on at least four occasions during the summer of 1969 , noting that this species was a rather dark, chocolate-red color and that the Long-tailed Weasels were a golden brown. Weasel tracks have been recorded on 8 of the last $13 \mathrm{CMCs}$ and may be attributed to this species. One was seen 27 December 1986. A species uncommonly seen.

\section{Long-tailed Weasel}

Anweiler saw this species on at least four occasions. One approached to within a few feet when he began "squeaking" on the back of his hand. Tracks of this species were seen on the 1 January 1976 CMC. Current status is uncertain; it is rarely seen.

\section{Least Weasel}

The Least Weasel was not recorded by Anweiler. It was live trapped by Driver on a study plot. Small weasels, either the Least Weasel or Ermine have been seen by the author on a number of occasions. Least Weasels are rarely seen.

\section{American Mink}

Anweiler listed mink as hypothetical. Tracks were seen on 5 of the last 13 CMCs. Mink are classed as fairly common although sighted only occasionally.

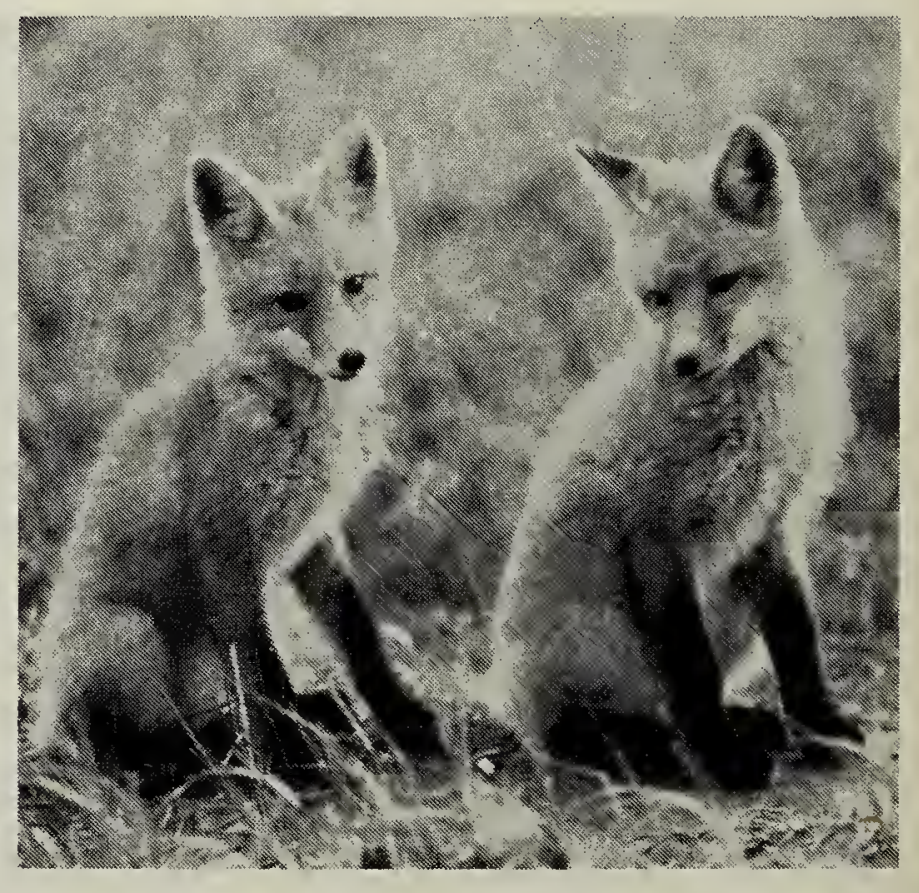

Red Fox kits

G.W. Beyersbergen 


\section{American Badger}

Anweiler listed the badger as hypothetical and probably an uncommon resident. Its presence has been recorded on 3 of the 13 CMCs. It has been a common resident with fairly regular sightings since 1973.

\section{Striped Skunk}

Skunks are very commonly seen from early spring until fall in all types of upland habitats. Tracks were seen 28 December 1975 (CMC) and 27 December 1986.

\section{Lynx}

John Hatfield reported to Anweiler the sighting of a Lynx crossing the prairie at the north end of Last Mountain Lake around 1967. From 1973 to the present, neither the mammal nor its tracks have been seen, thus this was a very rare transient.

\section{Mule Deer}

Anweiler and Hatfield saw a buck lying in a small ravine on 17 June 1969. There is a resident population of Mule Deer west of Highway \#2 and the occasional transient visitor is sighted. Two were seen 7 July 1987.

\section{White-tailed Deer}

White-tailed Deer were recorded by Anweiler in 1969, and commonly seen by the author since 1973. The north end of Last Mountain Lake is an important wintering area. Wintering population counts have varied from a low of 32 on 10 April 1975 , to a high of 134 on 9 February 1984. In February 1987, 109 Whitetail Deer were counted. They have been recorded on all $13 \mathrm{CMCs}$ and are very common.

\section{American Elk or Wapiti}

A single young bull elk was seen periodically between 12 August and 10 October 1987 on and near the wildlife area by several observers. The species is not expected to occur again except as a wanderer.

\section{Pronghorn}

Pronghorn (Antelope) have been seen periodically for short periods of time in the area and can only be classified as transients. A single Pronghorn was seen on 16 June 1987 by Driver and the author. They are rarely seen here.

\section{Conclusions}

It is evident that the status of mammals at Last Mountain Lake continues to change. Several species of prairie mammals have become extirpated in the Last Mountain Lake district in the past 150 years, including the Plains Bison, the wolf and the grizzly bear, while others like the Red Fox and Raccoon have increased. One species, the Long-tailed Weasel, has been classified as "threatened" in Canada by the Committee on the Status of Endangered Wildlife in Canada. Its current status at Last Mountain Lake is uncertain. It is probable that additional species will be recorded in the area.

1 ANWEILER, G. 1969. Records from field work at Last Mountain Lake, 1969. Unpublished field notes, Canadian Wildlife Service.

2 BANFIELD, A.W.F. 1974. The mammals of Canada. Univ. of Toronto Press, Toronto.

3 BURT, W.H. and R.P. GROSSENHEIDER 1976. A field guide to the mammals. Houghton Miffin Company, Boston.

4 DRIVER, E.A. 1983-1986. Progress reports on prescribed burning research, Last Mountain Lake Wildlife Management Unit. Canadian Wildlife Service, Saskatoon, Saskatchewan.

5 HATFIELD, J.P. 1965. Natural history notes - Last Mountain Lake Bird Sanctuary and vicinity. Queen's Printer, Ottawa.

6 NERO, R.W. 1959. Some recent mammal records. Blue Jay 17:169.

7 NERO, R.W. 1965. Recent pocket mouse records for Saskatchewan. Blue Jay 23:36-38. 